\title{
President's Message:
}

\section{The Year in Review-Open Everything Colleen Cuddy}

As I sit down to write my last president's column a variety of topics are running through my mind. But as I focus on just one word to sum up the year, "open" rises to the top of the list. For truly it was a year of all things open. My presidential theme is open data/open science and I am looking forward to hearing Tony Hey and Clifford Lynch speak at the LITA President's Program later this month on this topic. Dr. Lynch is also the recipient of this year's LITA/Library Hi Tech award for Outstanding Communication in Library and Information Technology, cosponsored by Emerald Group Publishing Limited. The prestigious Frederick G. Kilgour Award for Research in Library and Information Technology award, co-sponsored by OCLC, is being given to G. Sayeed Choudhury this year. Dr. Choudhury is a longtime proponent of open data and the award recognizes his leadership in the field of data curation through the National Science Foundation supported Data Conservancy project.

As you well know ITAL is now an open-access journal. Open access continues to be a hot topic, and rightly so. My last column was devoted to the subject of open access, but, I do want to remind librarians to advocate for open access in the coming year-please keep up the fight! In addition to seeing our journal to its new platform, the Publications Committee has also been busy with a few new LITA Guides, one of which, "Getting Started with GIS," by Eva Dodsworth, provides some guidance on harnessing data sets to work with geospatial technology. Ms. Dodworth will be conducting an online course on this topic in August and the Education Committee has many new courses in the pipeline.

Internally LITA has been working towards a more open and transparent governance structure. The Board has been relentless in making sure that all of its meetings are open, from in-person meetings at conferences to our monthly phone meetings to conversations on ALA Connect. We have been streaming our board meetings live and now will archive the recordings for a limited amount of time. This move has not been without challenges as board members and the LITA office struggled to build open communication with each other and the membership. Sometimes the challenges were ideological or legal, and sometimes the very technology that we embrace has caused problems, but I think it is safe to say that LITA leadership is working towards a common goal of a transparent structure with open communication channels.

Colleen Cuddy (colleen.cuddy@med.cornell.edu) is LITA President 2011-12 and Director of the Samuel J. Wood Library and C. V. Starr Biomedical Information Center at Weill Cornell Medical College, New York, New York. 
We opened up communication channels to get feedback on what our membership would like most when Zoe Stewart-Marshall, incoming president, hosted a town hall meeting at the ALA Midwinter Meeting that focused on member feedback. I know that she is working hard to address membership needs during her presidency.

As a medical librarian I often travel in circles outside of ALA and when my medical colleagues learned that I was LITA President they were really impressed. LITA is a well-known and wellrespected brand in the library community. Talking to my non-LITA colleagues reinforced the value that LITA brings to the entire profession, particularly through our programming, education, and they way in which we share and exchange information in open forums such as the LITA blog and listserv. (Of course I hope that we have gained some new members through this outreach!) Clearly we are doing many things right and we should not lose sight of what is great about LITA as we work on addressing areas that need improvement.

One thing that is consistently great about LITA is its annual sponsorship of ALA Emerging Leaders. This year we sponsored two LITA members who were part of the 2012 ALA Emerging Leaders cohort: Jodie Gambill and Tasha Keagan. Both were assigned to a team working on a LITA project that asked for a recommendation and plan for the implementation of a LITA Experts Profile System. The team was responsible for identifying the software to employ and creating an implementation plan with ontology recommendations. The team has identified VIVO (an opensource, semantic-web application) as the software for the project and will present its findings and implementation plan to the LITA Board and the ALA community at the ALA Annual Conference. The team did an outstanding job on this project and completed the deliverable on time, with very little guidance from LITA leadership - a sure sign of leadership! Yet, I was often reminded that as we embrace our upcoming leaders, we should not forget that leadership occurs on all levels. One message that I heard throughout my presidency is that LITA should do more for mid-career librarians-and this sentiment is shared by members of other organizations in which I am active. This is a challenge that LITA leadership is poised to take on as it balances its services to membership.

As I now count eighteen occurrences of the word "open" in this column I believe I have made my point and it is time to sign off. Although I am finishing up my duties as LITA President, I am not saying goodbye. I look forward to my new role as past-president, particularly in hosting the 2012 LITA National Forum in Columbus, Ohio (October 4-7): New World of Data: Discover. Connect. Remix. The National Forum Planning Committee led by Susan Sharpless Smith has done an outstanding job putting together an excellent meeting. The committee has lined up interesting speakers such as Eric Hellman, Ben Schneiderman, and Sarah Houghton, and thoughtfully evaluated many paper and poster submissions. I am sure we will all learn quite a bit from our colleagues as we attend sessions and network. I will be hosting a dinner and I hope to see some of you there as I enjoy what I hope will be a more relaxed role as past-president.

It has been an honor to serve you and I look forward to working with LITA in the years to come! 